The University of San Francisco

USF Scholarship: a digital repository @ Gleeson Library |

Geschke Center

Sport Management

College of Arts and Sciences

$1-1-2017$

\title{
Determining Fair Market Value for Duke’s Sporting Goods Store
}

Michael Goldman

University of San Francisco, mmgoldman@usfca.edu

Daniel A. Rascher

Follow this and additional works at: https://repository.usfca.edu/sm

Part of the Finance Commons, Sports Management Commons, and the Sports Studies Commons

\section{Recommended Citation}

Goldman, Michael and Rascher, Daniel A., "Determining Fair Market Value for Duke’s Sporting Goods Store" (2017). Sport Management. 27.

https://repository.usfca.edu/sm/27

This Article is brought to you for free and open access by the College of Arts and Sciences at USF Scholarship: a digital repository @ Gleeson Library | Geschke Center. It has been accepted for inclusion in Sport Management by an authorized administrator of USF Scholarship: a digital repository@ Gleeson Library | Geschke Center. For more information, please contact repository@usfca.edu. 


\title{
Determining fair market value for Duke’s Sporting Goods Store
}

\begin{abstract}
Shelley Valdez is a recent finance team hire at Duke's Sporting Goods Store. She has one week to identify, gather and analyze relevant information to calculate the financial value of the business, using the income and market approaches. She has also been asked to consider Duke's liquidation value, and comment on the strategic options these calculations point to, before a board meeting of the owners next week.
\end{abstract}

\section{Determining fair market value for Duke’s Sporting Goods Store}

After her first week of settling in to her fulltime position at Duke's Sporting Goods Store, Shelley Valdez was looking forward to her scheduled project meeting with Ashlin Munro, the recently appointed Finance Director. Valdez had accepted a permanent finance team role at Duke's just after completing her part-time graduate management studies in early December of the current year. During the previous two years as a student, she had completed a number of senior internship roles, including working with the World Triathlon Corporation and Ironman triathlon brand, where she had supported a finance team valuing the purchase of a new event. She had also spent time with a local NBA franchise, where she contributed data gathering and analysis support to value the Esports live gaming team linked to the franchise. In accepting this fulltime role at Duke's Valdez was excited about the opportunity to develop stronger management capabilities while at Duke's, while also appreciating the family-friendly culture and active lifestyle she was encountering in the business.

As Valdez took her seat in Munro's office, he outlined the dilemma facing Duke's. After a lengthy period of high growth and profitability, the business was taking strain. Munro was concerned that increased competition via ecommerce and changing consumer behavior were eroding Duke's market share and slowing topline growth. Munro admitted to Valdez that he had been brought back into a management role within the business in order to get a clearer understanding of the financial health of the store, as well as to evaluate the most appropriate strategic direction for Duke’s. Munro needed Valdez's urgent help to calculate a financial valuation for the business, in order for the owners to decide how to proceed at next week's board meeting. The Finance Director asked Valdez to use the income approach, as well as the market approach, to determine Duke's fair market value, and also to consider Duke's liquidation value (given that the lease will be ending soon, allowing Duke's to liquidate if that was decided). He stressed the sensitivity of these discussions, especially the third option, and reminded her to only discuss this exercise with him.

\section{Duke's}

Duke's Sporting Goods Store was an apparel retailer of sporting goods. The private company sold sports apparel, gloves, footwear, equipment, and accessories to amateur and recreational athletes in a mid-sized West Coast city in the U.S. By the end of the current 
financial year, the company's cash-on-hand will be $\$ 100,000$, with an additional $\$ 400,000$ worth of inventory (based on cost), and $\$ 25,000$ in accounts receivable. Three running friends, Aaron Fox, Alessandro Devine, and Ashlin Munro, who recognized a need to provide quality running footwear and apparel to the community, founded the business twenty years ago. The three partners contributed $\$ 50,000$ start-up capital each and were able to rent a small empty store near the center of town. Although the partners had considered opening additional stores during the past decade, Duke's had remained a singlestore business, serving the community that had grown around it. As customer demand grew, including requests for sporting goods beyond running, Duke's broadened their product range to include football, basketball, baseball, soccer, swimming, cycling, and rugby. In the event of liquidation, Valdez had learned that Duke's inventory could be sold in a "going out of business sale" for an average discount of $50 \%$ of its cost, and its longterm asset of furniture, fixtures \& equipment (FFE) could be sold at $50 \%$ of its current level of $\$ 100,000$

Munro briefed Valdez that Duke's liabilities were accounts payable of $\$ 75,000$ and accrued expenses, taxes, and wages of $\$ 75,000$, and that accounts receivable could be sold to a collections agency for $40 \%$ of its current level.

Figure 1: Duke’s Sporting Goods Store selected financial indicators (\$’s in Thousands)

\begin{tabular}{|l|r|r|r|r|}
\hline & FYE CY-3 & FYE CY-2 & FYE CY-1 & FYE CY \\
\hline Revenue & 1,000 & 1,200 & 1,400 & 1,500 \\
\hline Cost of goods sold & 500 & 600 & 700 & 750 \\
\hline Gross profit & 500 & 600 & 700 & 750 \\
\hline SG\&A & 300 & 350 & 400 & 425 \\
\hline R\&D & 25 & 30 & 35 & 40 \\
\hline EBITDA & 175 & 220 & 265 & 285 \\
\hline Depreciation \& amortization & 25 & 25 & 25 & 25 \\
\hline EBIT & 150 & 195 & 240 & 260 \\
\hline Interest expense & 0 & 0 & 0 & 0 \\
\hline EBT & 150 & 195 & 240 & 260 \\
\hline Effective tax rate & $40 \%$ & $40 \%$ & $40 \%$ & $40 \%$ \\
\hline Income tax expense & 60 & 78 & 96 & 104 \\
\hline Net Income & 90 & 117 & 144 & 156 \\
\hline
\end{tabular}

Notes to financial indicators:

1. The company uses straight-line depreciation. DA is expected to be consistent, given that the equipment and capital expenditures are being used to obtain fixed assets that are depreciable. The physical depreciation and/or amortization of fixed assets is allowed to be booked as an expense, thus lowering the taxable income. Yet, it is not an actual decrease in dollars so it is not a decrease in cash flow.

2. Sourced from Fiscal Year Ending (FYE) Current Year (CY) from audited financial statements and business forecasts. 


\section{Sporting goods industry}

Sporting goods store sales in the U.S. had increased from \$15.58 billion in 1992 to approximately $\$ 45$ billion in $2014^{\mathrm{i}}$. Analysts suggested this growth had been driven by an increased desire among Americans to maintain health, enjoy greater amounts of recreational time, and take advantage of newer fitness technologies and activities. Others also pointed to increased sports participation rates and product innovations such as lightweight, breathable micro fibers ${ }^{\text {ii. }}$. Steve Currie, a Partner at Catalyst Corporate Finance argued:

Consumers are demanding functional apparel that has a combination of performance, fit and fashion. The sports apparel market now accounts for approximately $15 \%$ of the overall clothing market globally and most industry leaders believe the trend of men and women increasingly wearing athletic apparel in casual settings is a permanent shift in the broad appeal of functional appareliii.

Including online sales, consumers in the U.S. spent almost $\$ 64$ billion on sporting goods in 2014. Globally, over $\$ 260$ billion was spent on sportswear during 2013. The market was forecast to grow in North America at 3.7\% CAGR, with the highest growth internationally expected in Latin America and Eastern Europe ${ }^{\mathrm{iv}}$. In the U.S. annual revenues in the sporting goods industry were believed to have grown by $2.3 \%$ between 2011 and $2016^{\mathrm{v}}$, while the online and in-store U.S. outdoor and sporting goods market grew by $5 \%$ in year-on-year sales from 2015 and $2016^{\text {vi }}$.

By 2014, sporting goods stores were still more popular outlets for buying athletic gear than online channels. During that year Internet retailing accounted for $12 \%$ of total apparel sales in Western Europe and North America ${ }^{\text {vii }}$. Analysts explained the closure of some stores and declining footfall in mid-to-low shopping malls by changing shopping habits and macroeconomic factors, such as declining discretionary incomes and aggressive online pricing. An industry executive reflected that consumers' "day-in, day-out shopping habits have changed and they don't come into the stores as often.”viii By early 2017, the shift to online purchases had seen numerous recent retail bankruptcies, including Sports Authority, MC Sports, Golfsmith, Sports Chalet, Eastern Outfitters, Total Hockey, and Payless, resulting in the closure of hundreds of stores ${ }^{\mathrm{ix}}$. Physical store sales for companies in the sporting goods, hobby store, book, and music sector dropped 6.9\% during the 2016 holiday shopping season, while online sales increased by $19 \%^{\mathrm{x}}$.

The role of bricks-and-mortar stores was also changing, with some online retailers opening showrooms that allowed customers to try on items, evaluate quality and place orders, but which did not hold inventory. Dick’s Sporting Goods, for example, opened 36 new stores in 2016 and invested in it's e-commerce platform. The retailer also experimented with new speciality store formats, private labels, and branded store-within-store concepts, such as the Nike Field House. One analyst suggested:

Retailers who get it know that a store is shifting from a place to stock and sell goods and is becoming an experience that develops brand relationships. Retailers who 
offer unique, tailored experiences of the brands they carry -- and of their own brands, through services, content, and community -- can still attract droves of customers to their stores ${ }^{\mathrm{xi}}$.

Duke's planned to respond to these industry shifts by installing a series of interactive sporting experiences for customers over the next 3-4 years, as well as strengthening Duke's online sales platform. Munro mentioned Duke's capital expenditure (CAPEX) investment of \$50,000 in a Surround HD Sports Simulator, which would be installed in the coming months. Customers would be able to practice and improve their soccer, basketball, icehockey, tennis, rugby, and golf skills, while trying out Duke's range of equipment and apparel. Duke's was also investigating virtual reality headsets, environments, and games to support their football range of products next year. Munro suggested that CAPEX would be constant over the coming years as Duke's consistently and constantly invested in its future. Munro also directed Valdez to be conservative in her industry growth estimate and assume $2.0 \%$ perpetual growth rate of net cash flow for the terminal year and beyond.

\section{Competitors}

During her orientation to Duke's, Valdez had heard others refer to three comparable businesses with whom they competed. Munro had provided login access for Valdez to use the databases of the National Association of Certified Valuators and Analysts (NACVA) to gather more complete data on these competitors. She used NACVA's proprietary 7,000 sales transactions DoneDeals $®$ database to search corporate transaction details and multiples on the sales of mid-size companies, as well as the proprietary 12,000 sales transactions in BIZCOMPS ${ }^{\circledR}$ database that provided this data for small business transactions under $\$ 1$ million. These databases contained annual revenue, income, and transaction pricing information on the three competitors to Duke's.

\section{Charlie’s Sporting Goods}

Charlie's was located in a neighboring town and served a similar set of customers to Duke's. The business was seven years old and had generated steady revenues and net income over the past three years. Charlie's had been acquired two years ago for \$1.0 million, and had recently sold $5 \%$ of it for $\$ 40,000$.

\section{Mary’s Sporting Goods}

Mary's was located a few towns away from Duke's and specialized in women's and girls' sporting goods. The business had existed for over a decade and drew from a larger market area than Duke's. Mary's offered free training on its equipment, which added to its expenses, although, management was of the opinion that this choice grew their customer base and sales. Mary's had been acquired outright in the current year for $\$ 2$ million. 


\section{Jamie’s Sporting Goods}

Jamie's was a three-store chain located on the north and south sides of the nearest large city. It had been operating for over two decades. Jamie's recently added its third store, financing this expansion with a loan from a local bank, resulting in substantial interest payments. While it produced a high net income, it was more leveraged that Mary's Sporting Goods or Charlie's Sporting Goods. The current owners had sold 8\% of the business for $\$ 350,000$ in the current year.

Figure 2: Competitor selected financial indicators (\$’s in Thousands)

\begin{tabular}{|l|r|r|r|}
\hline & Charlie's & \multicolumn{1}{|c|}{ Mary's } & \multicolumn{1}{|c|}{ Jamie's } \\
\hline Total revenues (CY) & 1,000 & 2,000 & 5,000 \\
\hline Total expenses (CY) & 900 & 1,850 & 4,200 \\
\hline Net Income & 100 & 150 & 800 \\
\hline & & & 500 \\
\hline Current assets (minus inventory) & 100 & 250 & 2,000 \\
\hline Current liabilities & 100 & 150 & 1,500 \\
\hline Inventory & 300 & 550 & \\
\hline
\end{tabular}

\section{Calculating fair market value}

Valdez recalled her previous financial management course and her internship experiences as she started analyzing the data she had collected. She knew that the first step in using the income approach was to forecast income for Duke's for the next three years, and then calculate net cash flow, then discounted cash flow, and finally net present value. She was conscious that Munro had also asked her to consider the market approach, and she wondered how these two solutions could be integrated into a single estimate or range of value. Having just joined the business, she was concerned about the possible implication of Munro's request for a liquidation value, and wondered which strategic direction the owners would consider in their upcoming board meeting. 


\section{Discussion Questions}

1. Forecast Revenues and Expenses for Current Year $+1(\mathrm{CY}+1), \mathrm{CY}+2, \mathrm{CY}+3$, and Terminal Year. For this case study, use only the previous year's Revenues and Expenses, as well as the industry information in the case, as a guide. Come up with your own reasonable forecast.

2. Calculate the Net Income for CY+1, CY+2, CY+3, and Terminal Year.

3. Calculate the Net Cash Flow for $\mathrm{CY}+1, \mathrm{CY}+2, \mathrm{CY}+3$, and Terminal Year. As explained in most valuation textbooks, there are a number of steps to get to Net Cash Flow from Net Income. In terms of Current Assets, exclude Inventory, since; even though Inventory is technically a Current Asset, a manager would not want to rely on inventory to pay workers. Make a reasonable assumption for changes in Net Working Capital for future years.

4. Calculate the Net Present Value (NPV) of Duke's using the Discounted Cash Flow method (a method within the Income Approach)

5. Use the Market Approach to determine a financial value for Duke’s.

6. Calculate the relevant ratios for the comparable businesses.

7. Adjust the financial value of Duke's for a controlling interest premium and marketability discount, if needed.

8. What is the Liquidation Value of Duke's?

9. Based on the Fair Market Value assessments, and Liquidation Value, what strategic options could Duke's owners consider? 


\footnotetext{
i Statista. (2015). Sporting goods store sales in the United States from 1992 to 2014 (in billion U.S. dollars). Retrieved from https://www.statista.com/statistics/197704/annual-sporting-goods-store-sales-in-the-ussince-1992.

ii Catalyst Corporate Finance. (2014). Global Sportswear Sector M\&A update. Retrieved from www.catalystcf.co.uk.

iii Catalyst Corporate Finance. (2014). Global Sportswear Sector M\&A update. Retrieved from www.catalystcf.co.uk.

${ }^{\text {iv }}$ Catalyst Corporate Finance. (2014). Global Sportswear Sector M\&A update. Retrieved from www.catalystcf.co.uk.

${ }^{\vee}$ Gaille, B. (2017). 36 astonishing sporting goods industry trends. Retrieved from https://brandongaille.com/39-astonishing-sporting-goods-industry-trends.

vi Taylor, G. (2017). Amazon plays hardball: Outscores Sporting Goods growth rate by 4X in 2016. Retrieved from https://www.retailtouchpoints.com/topics/e-commerce/amazon-plays-hardball-outscoressporting-goods-growth-rate-by-4x-in-2016.

vii Kissane, B. (2015). End of the line for traditional bricks-and-mortar stores in apparel? Euromonitor International.

viii Bomey, N. (2017). Why sporting goods stores are down for the count. USA Today. Retrieved from https://www.usatoday.com/story/money/2017/03/07/sporting-goods-stores-retail-bankruptcy/98682338/. ix Thompson, D. (2017). What in the World is Causing the Retail Meltdown of 2017? The Atlantic. Retrieved from https://www.theatlantic.com/business/archive/2017/04/retail-meltdown-of-2017/522384. x Bomey, N. (2017). Why sporting goods stores are down for the count. USA Today. Retrieved from https://www.usatoday.com/story/money/2017/03/07/sporting-goods-stores-retail-bankruptcy/98682338/. ${ }^{x i}$ Lee Yohn, D. (2016). What Sports Authority and Dick's Sporting Goods indicate about the state of the retail industry. Forbes. Retrieved from https://www.forbes.com/sites/deniselyohn/2016/03/30/what-sportsauthority-and-dicks-sporting-goods-indicate-about-the-state-of-the-retail-industry/\#59514697489b.
} 